\title{
Video razlage kot učinkovit element izobraževanja v COVID 19 situaciji
}

\author{
Igor Pesek ${ }^{1}$, Blaž Zmazek ${ }^{1,3}$, Alenka Lipovec ${ }^{1,2}$ \\ ${ }^{1}$ Fakulteta za naravoslovje in matematiko, ${ }^{2}$ Pedagoška fakulteta, Univerza v Mariboru, ${ }^{3}$ ARRS \\ igor.pesek@um.si blaz.zmazek@um.si alenka.lipovec@um.si
}

\begin{abstract}
Povzetek
V prispevku podamo trenutno stanje znanstvenih ugotovitev o obrnjenem učenju v krizni situaciji in primerjamo dva modela, kitajskega in slovenskega. Marca 2020 je izšel priročnik, ki opisuje kitajsko izkušnjo o tem kako zagotavljati učenje tudi med izbruhom COVID-19. V Sloveniji je konec marca zaživelo gibanje Razlagamo.si, ki ponuja asinhrone (vnaprej posnete) video razlage, ki učečemu omogočajo samostojno razpolaganje s časom in dodatno sinhrono komunikacijo o evidentiranih problemih v skupinskih ali individualnih pogovorih. $\mathrm{V}$ prispevku opišemo portal Razlagamo.si in ga primerjamo s kitajskimi smernicami. Na osnovi zaznanih prednosti in slabosti ponudimo model, ki je vzdržen tudi v situaciji, ko je le del populacije učencev in dijakov vključen v izobraževanje na daljavo. Ponudimo tudi kvantitativni pregled video razlag po predmetih in področjih. Prispevek bo v pomoč učiteljem, ki poučujejo po načelih obrnjenega učenja in odločevalcem, ki razmišljajo o modelu izobraževanja $\mathrm{v}$ prihodnosti.
\end{abstract}

Ključne besede: obrnjena učilnica, asinhrono učenje, digitalni vir,

\section{Uvod}

Svetovna zdravstvena organizacija (WHO) je 30. januarja 2020 proglasila COVID-19 za globalno nesrečo, 11. marca 2020 pa razglasila pandemijo. Vpliv e-izobraževanja je močno raziskovano področje, ki je posebej pridobilo na pomenu v krizi COVID-19. V krizni situaciji so namreč mnoge države zaprle šole in prešle na poučevanje na daljavo. Učinkovitost tega ukrepa je še vedno stvar debate (Viner, in drugi, 2020).

Zaradi izrazito velikega števila raziskav smo se v našem prispevku poskušali omejiti na meta analize, kjer je to le bilo mogoče. Dosedanje raziskave ne nakazujejo, da bi uporaba IKT imela statistično značilen vpliv na znanje učencev, kažejo pa se izrazite prednosti IKT pri razvoju bolj avtonomnega učenja (Hatlevik, Throndsen, Loi, \& Grudmundsdottir, 2018). Meta analiza, ki jo je opravil Clark s sodelavci (Clark, Tanner-Smith, \& Killingsworth, 2016), trdi, da lahko IKT kot medij spodbuja produktivno učenje. Podobne rezultate daje novejša meta- 
analiza, kjer Baseer Safi (2019) ugotavlja, da ima vključevanje IKT v izobraževanje lahko pozitivne učinke na administratorje, učitelje in učence (Baseer Safi, 2019). V nekoliko starejši meta-analizi pa Means s sodelavci (Means, Toyama, Murphy, Bakia, \& Jones, 2009) na osnovi več kot 100 IKT študij iz izobraževanja ugotavlja, da najmočnejši pozitivni učinek na znanje učencev dosežemo s kombinirano metodo poučevanj ob uporabi digitalnih manipulatorjev, ki vzpodbudijo aktivno učenje.

Ves čas raziskovalci s tega področja poudarjajo kvaliteto e-učnih materialov. Clark in Mayer (2008), izpostavita, da za kakovost e-učnih materialov ni dovolj jasnost vsebine in interaktivnost ter da lahko interaktivni in dinamični elementi igrajo konstruktivno ali destruktivno vlogo v učnem procesu. Lahko so učinkovito orodje za zagotavljanje aktivne vloge učenca, saj podatke predstavljajo na bolj nazoren način in spodbujajo poglobljeno razumevanje vsebin; po drugi strani pa lahko napak uporabljena interaktivnost vodi k izgubi pozornosti učečega (Lipovec, Zmazek, Lah, Zmazek, \& Zmazek, 2017). Čeprav raziskovalno rezultati na tem področju niso konsistentni pa je široko sprejeta hipoteza, da bodo računalniki v učilnicah prihodnosti igrali vlogo spodbujevalcev kognicije (Pérez-Sanagustín, in drugi, 2017).

V času COVID krize smo lahko večkrat prebrali, da poučevanje na daljavo krepi socialno ekonomske razlike. Tudi raziskovalno rezultati podpirajo to tezo. Scherer in Siddiq (2019) v svoji meta analizi (Scherer \& Siddiq, The relation between students' socioeconomic status and ICT literacy: Findings from a meta-analysis., 2019) ugotavljajo, da je sicer vrzel v digitalni pismenosti, ki nastane zaradi povezave med socialno ekonomskim statusom, manjša kot vrzel, ki jo SES povzroči pri npr. dosežkih iz matematike. Kljub temu pa je povprečni Pearsonov $\mathrm{R}=0.214$ in pojasni približno $17 \%$ variance znotraj vzorca. Po drugi strani pa ista avtorja (Siddiq \& Scherer, 2019) ugotavljata, da spol nima večje vloge pri IKT pismenosti.

\section{Obrnjena učilnica}

Pristop obrnjenega učenja (ang. flipped learning) je postal priljubljena pedagogika $\mathrm{v}$ mnogih izobraževalnih zavodih po vsem svetu. Tudi v situaciji COVID-19 se večkrat uporablja obrnjeno učenje z vnaprej pripravljenimi video posnetki (Lipomi, 2020). Učenci dobijo vnaprej pripravljena gradiva, ki jih asinhrono pregledajo, nato pa v sinhroni komunikaciji z učitelji razčistijo morebitne nejasnosti. Obrnjeno učenje je priznano kot učinkovita metoda poučevanja tudi izven kriznih časov (Najafi \& Heidari, 2019). Wagner, Gegenfurtner, \& Urhahne (2020) v svoji meta-analizi model obrnjene učilnice definirata kot poučevalni pristop, kjer učenci najprej doma pogledajo izobraževalni video posnetek, ki je bil pripravljen za namene poučevanja $\mathrm{v}$ obrnjeni učilnici, nato pa $v$ šoli izvajajo nadaljnje aktivnosti učenja in poučevanja (Wagner et. 
al, 2020). Posebej torej izpostavita video posnetke. V meta-analizi 44 neodvisnih virov ugotavlja, da je model obrnjene učilnice za srednješolce bolj učinkovit kot tradicionalno poučevanje, vendar le za STEM (Science, Technology, Engineering, Mathematics) predmete. Van Alten s sodelavci (2019) podobno opredeli obrnjeno učilnico kot pristop, kjer »učenci najprej preučijo poučevalne vire (npr. gledajo online predavanja) in nato znanje uporabijo $\mathrm{V}$ učilnici« (van Alten, Phielix, Janssen, \& Kester L., 2019). Iz meta-analize je razbrati, da dobro oblikovana obrnjena učilnica v srednji šoli predstavlja obetaven pedagoški pristop prihodnosti, zaznan je tudi majhen pozitiven učinek na dosežke. Do podobnih rezultatov so na populaciji osnovnošolcev prišli Zhu, Suárez, Thompson, \& Peng (2019). Glavne težave pri uporabi obrnjenega učenja vključujejo veliko delovne obremenitve učiteljev pri ustvarjanju obrnjenih učnih gradiv in znižano aktivnost učencev pri učenju izven učilnice (Lo \& Hew, 2017).

Raziskave, ki se dotikajo tehnologije in faktorjev, ki določajo sprejemanje le-teh s stališča učiteljev potekajo že nekaj časa (Scherer \& Teo, 2019), saj gre za kompleksen konstrukt, na katerega vpliva mnogo dejavnikov. Grobo pogledano, sprejemanja tehnologije ne moremo določiti le skozi pogoje, ki jih šole ponujajo učiteljem kot pomoč pri uporabi tehnologije, ampak je sprejemanje določeno tudi s spektrom motivacijskih sledi učiteljev, samoprepričanj in prepričanj o tehnologiji in njihovi uporabi. V COVID-19 krizi izvajanje eučenja ne teče vedno gladko in učinkovito, saj imajo šole omejene izkušnje z e-učenjem, zlasti kadar učitelji ne razumejo principov poučevanja na daljavo (Almanthari, Maulina, \& Bruce, 2020).

\section{Kitajska izobraževalna izkušnja s COVID-19}

Marca 2020 je izšel priročnik, ki opisuje kitajsko izkušnjo o tem, kako zagotavljati učenje tudi med izbruhom COVID-19. Huang s sodelavci (2020) opiše kako je kitajsko ministrstvo med izbruhom vzpostavilo iniciativo »Disrupted classes, undisrupted learning«, ki je omogočila učenje na daljavo več kot 270 milijonom učencem. Strategije, ki so jih učitelji uporabljali so bile zelo raznolike, vse od skupinske uporabe videokonferenčnih sistemov kot je npr. Zoom ali Teams do sinhronega z videom podprtega poučevanja ena na ena. Opisujejo tudi raznolika gradiva za učence, ki so jih uporabljali. Pri tem posebej na več mestih izpostavijo posneta predavanja ( Huang et al, 2020, str. 5, 14), ki so bila že prej zaznana v literaturi kot učinkovita (Gordon, 2014). Huang s sodelavci iz kitajske izkušnje priporoča odprte digitalne učne vire, kamor uvršča široko paleto digitalnih virov, kar vključuje fotografije, avdio in video simulacije, animacije ipd. Navede pet kriterijev, ki jim morajo učni viri v situaciji kot je COVID-19, zadoščati: 
(a) primernost vsebine: učni viri morajo biti močno povezani z učnimi cilji in vsebinami ter dovolj zanimivi.

(b) Primernost težavnosti: vsebina mora biti raznolika v zahtevnosti, da preprečimo kognitivno preobremenitev učencev.

(c) Primernost strukture: struktura učnih materialov mora bili koncizna in racionalna, da učencev ne »zmede«.

(d) Primernost izbranega medija: medij mora posebej pri mlajših učencih biti izbran tako, da ne povzroči vizualne preobremenjenosti.

(e) Primernost organizacije virov: raznoliki viri (npr. video posnetki, animacije, tekst, virtualni eksperimenti) morajo biti predstavljeni strukturirano in jasno s stališča učenca. (Huang et al, 2020, str. 22).

$\mathrm{Na}$ Kitajskem so vsem učiteljem med COVID-19 krizo omogočili odprt dostop do digitalnih učbenikov. Dodajmo takoj, da imamo v Sloveniji prosto dostopne i-učbenike https://www.iucbeniki.si/. Predstavljena je tudi struktura organizacijskih oblik online poučevanja. Posebej izpostavimo, da znotraj razdelka asinhronega poučevanja zapišejo, da »učitelji morajo biti sposobni izdelati učne vire kot npr. videoposnetke in oblikovati online učne aktivnosti« (Huang s sodelavci, 2020, str. 28). Zapišejo tudi sedem jedrnih elementov učinkovitega izobraževanja v krizni situaciji.

1. Zagotavljanja učinkovite internetne mreže, ki omogoča vsem učencem (a) sinhrono poučevanje z video konferencami, (b) uporaba (gledanje, nalaganje) interaktivnih učnih virov (video posnetkov, iger ipd.) in (c) sodelovanje s sošolci preko socialnih omrežij

2. Izbira uporabniško prijaznih orodij pri čemer je treba biti posebej pozoren na to, da se učencev in staršev ne obremeni z zahtevo po uporabi mnogih aplikacij in platform. Šole pozivajo, da učitelji koordinirano uporabljajo iste platforme.

3. Zagotavljanje primernih interaktivnih digitalnih virov, kot so npr. video mikro tečaji, e-knjige, simulacije, animacije, kvizi in igre.

4. Vodenje učencev pri uporabi učinkovitih učnih metod, kar vključuje online skupnosti, ki omogočajo reden človeški online stik za preprečevanja občutka osamljenosti in nemoči.

5. Promocija učinkovitih metod, ki omogočajo raznolike poučevalne strategije kot je npr. diskusije, učenje z raziskovanjem, izkušenjsko učenje ipd.

6. Zagotavljanje hitrih podpornih servisov za učitelje in učence. 
7. Spodbujanje sodelovanja med vsemi deležniki (npr. ministrstva, raziskovalne organizacije, šole, starši). (Huang s sodelavci, 2020, str. 40).

\section{Skupna izobraževalna točka Razlagamo.si}

V nadaljevanju bomo opisali portal razlagamo.si, ki je nastal v Sloveniji v marcu 2020. Vsi, ki se v Sloveniji ukvarjajo z izobraževanjem, se v teh dneh soočajo z izzivi, ki jih je prinesla nova in nepoznana situacija. Tri fakultete Univerze v Mariboru, ki izobražujejo bodoče učitelje, Fakulteta za naravoslovje in matematiko, Pedagoška fakulteta in Filozofska fakulteta, so kot odgovor pripravile skupno izobraževalno podporno točko Razlagamo.si https://razlagamo.si/, ki je namenjena medsebojni pomoči pri izobraževanju na daljavo. Temeljna elementa portala so Gradiva in video razlage ter Podporni pogovori.

Pri podpornem pogovoru učenec zastavi vprašanje, na katero odgovori prostovoljec, študent ali učitelj. V tej komunikaciji se individualno rešujejo manjši problemi in evidentirajo vprašanja. Na Sliki 1 vidimo primer pogovora.

\section{Slika 1}

Podporni pogovori, matematika 6.razred

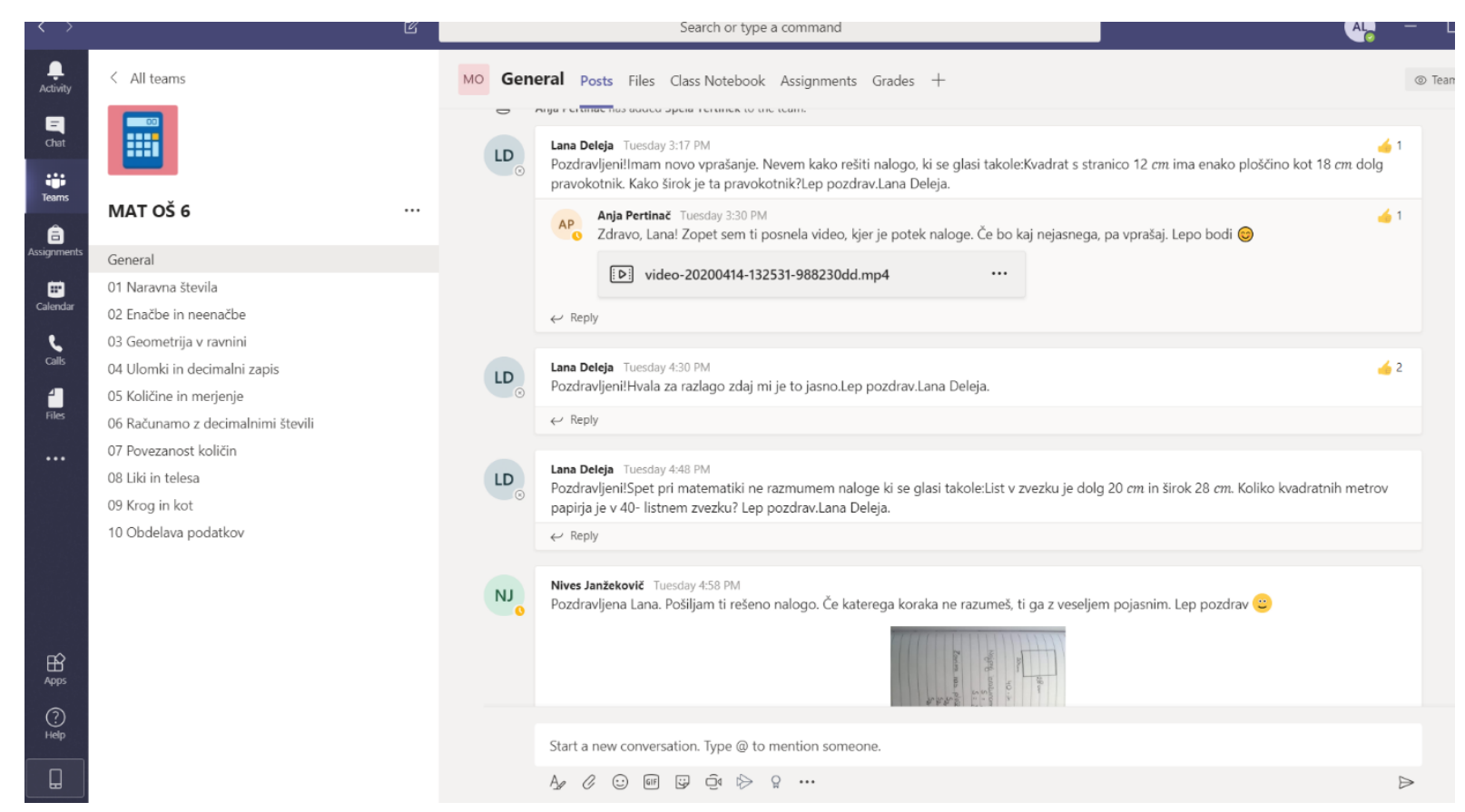

Pogovori so različnih tipov: včasih je na vprašanje možno odgovoriti statično, z besedilom ali sliko, včasih je potrebno posneti kot odgovor video posnetek, včasih pa je 
potreben sinhron pogovor, da se vprašanje pojasni. Pogovori potekajo v aplikaciji MS Teams. Učenec izpolni preprost prijavni obrazec in prejme uporabniško ime in geslo za vpis v razlagamo.si MS Teams. Na voljo so kratka navodila in video vodič. S klikom na povezavo pri posameznem predmetu se učenec oz. dijak vključi v ekipo, v kateri se izvajajo pogovori. Pogovori pokrivajo več kot 100 predmetov v osnovni in srednji šoli, vključeni so tudi predmeti v glasbeni šoli. Dodatno pa je v posebni ekipi ponujeno tudi svetovanje ob težavah pri učenju. V pogovorih delujejo študenti vseh treh fakultet različnih smeri, od študentov pedagoških naravoslovnih in družboslovnih smeri do psihologov. Trenutno je vključeno približno 250 študentov prostovoljcev, sodelujejo pa tudi nekateri učitelji. Učenci so po potrebi usmerjeni v zbirko Gradiva in video razlage, kjer bodo našli dodatno pomoč. Nastaja pregledna zbirka gradiv in video razlag, ki pri večini predmetov sledi strukturi potrjenih, prosto dostopnih i-učbenikov na www.iucbeniki.si in je torej v skladu z učnim načrtom.

\section{Video razlage}

Video posnetki se, kot že omenjeno, pogosto uporabljajo pri obrnjenem učenju. A tudi pri bolj tradicionalnem poučevanju je video posnetek učinkovito sredstvo. Ljudje bolje razumejo izgovorjeno besedo kot pisano besedo (Pinker, 2015). Še več, z uporabo videoposnetka je mogoče s kretnjami in izrazom obraza sporočiti več kot le $\mathrm{z}$ besedilom.

Video razlaga je video posnetek, ki sledi načelom metode razlage. Metoda razlage ali Sokratova metoda je tradicionalno ena izmed najbolj uporabljanih in tudi relativno učinkovitih metod poučevanja na različnih področjih (Overholser, 2018), tudi pri e-učenju (Liu, 2019). Sokratovo metodo Delić in Bećirović (2016) opredelita kot "pedagogiko, ki z vodenimi vprašanji pomaga učencem kritično razmisliti o njihovem razumevanju določene problematike (Delić \& Bećirović, 2016, str. 516-517). Metoda razlage v asinhronem video posnetku seveda sledi drugim principom kot sinhrona uporaba te metode. Učitelj običajno po zastavljenem vprašanju pusti učencem nekaj časa, v katerem lahko reflektirajo odgovor in nato nadaljuje tako, da ponudi nekatere izmed pričakovanih (pravilnih ali napačnih) odgovorov. Video posnetek lahko pri razlagi vključuje »realne« video posnetke (npr. posnetke naravnih pojavov), posnetke virtualnih manipulatorjev (npr. virtualne verzije eksperimentov) ali pa posnetke zaslona. Običajno video razlaga vsebuje kombinacijo vsega navedenega.

Na portalu razlagamo.si najdemo dve vrsti razlag, in sicer: a) razlage za usvajanje in ) razlage za utrjevanje. Prisotnost video razlage ob poglavju nakazuje ikona kamere (Slika 2). 


\section{Slika 2}

Video razlage, matematika, 8.razred

\section{Gradiva in video razlage}

Spodaj so že naložena gradiva za nekatere predmete. Gradiva bomo sproti še dodajali. Vabljeni k ogledu!

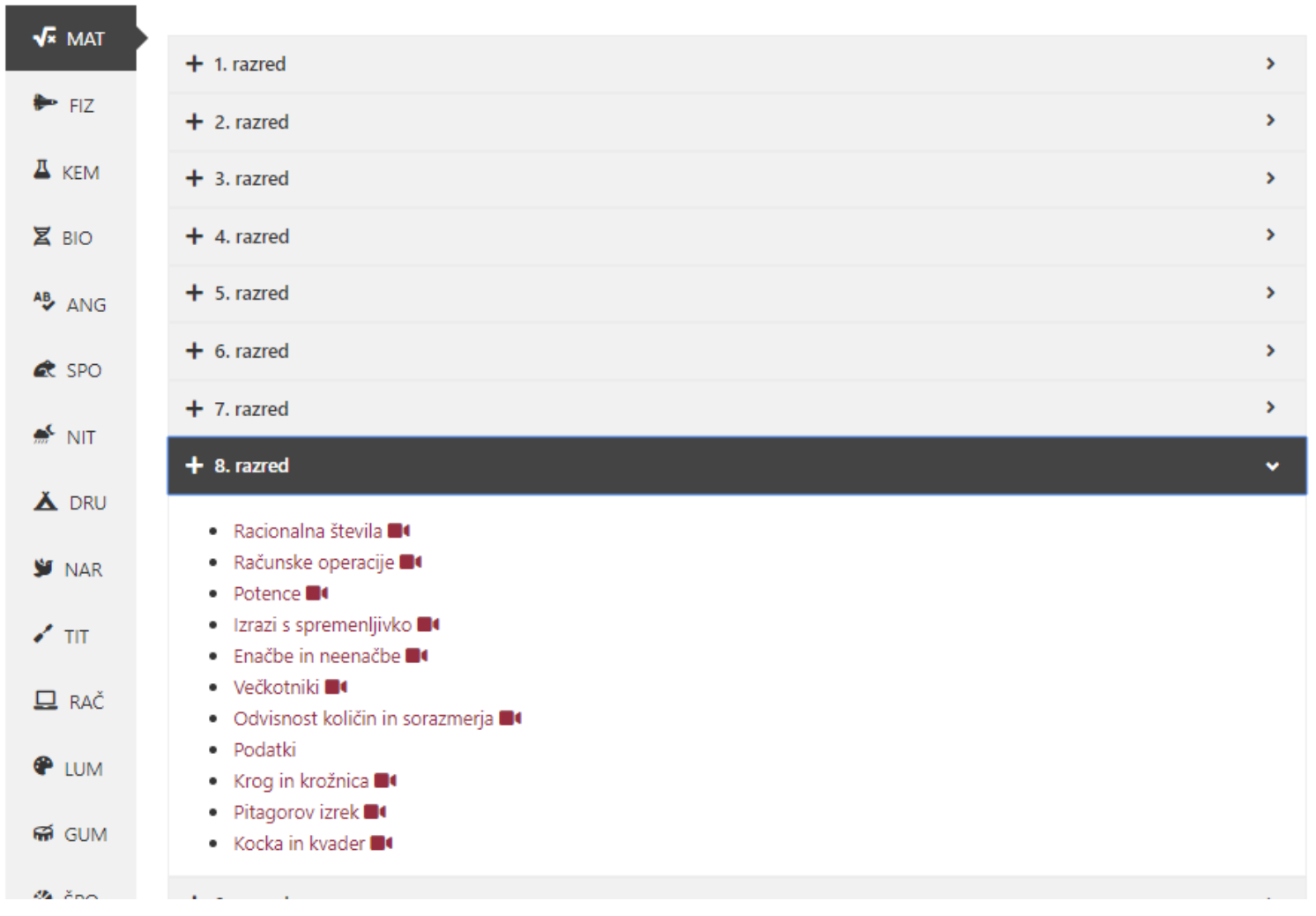

Razlaga za usvajanje sledijo sledečim smernicam: video razlaga ni daljša od 15 minut, vključuje največ dva osrednja pojma, vključuje kratko motivacijo in osmislitev pojmov, poudari razumevanje, vključi elemente povzetka in vsebuje pojasnitev največ štirih primerov. Pri Razlagi za utrjevanje pa so smernice sledeče: utrjevanje je pripravljeno le za ključne naloge, ni daljše od 10 minut in, ponovno, poudari razumevanje. V Razlagi naj predavatelj: uporablja strokovne izraze in vsebine podaja strokovno korektno, govori dovolj počasi, če piše prostoročno, piše čitljivo, v uvodu poda smerokaz na gradiva in cilje, med razlago lahko tudi zastavlja vprašanja, kot da so učenci prisotni, se osredotoča na ključne polje v vsebini, na koncu naredi povzetek s pregledom ključnih pridobljenih znanj in uporablja inovativne pristope in spletne interaktivne učbenike. Pri uporabi IKT orodij, ki so potrebni za pripravo 
video razlag, kot so programi za zajemanje in urejanje videoposnetkov ter zvočnih posnetkov, predavataljev nismo omejevali ali jim predpisovali, kaj naj uporabljajo. Smo pa jim svetovali v primeru, ko so potrebovali tehnično pomoč. Drugih tehničnih zahtev nismo postavljali, razen da je na video razlagi razločno vidno in slišno, kaj razlagajo. Pri tem so bili predavatelji zelo invetivni, saj so uporabljali različne pristope od tablic (od grafičnih do splošnih), spletnih kamer, telefonov, ki so jih stabilizirali in posnetkov pred tablo.

\section{Metodologija}

Namen raziskave je odgovoriti na naslednji dve raziskovalni vprašanji:

1. V kolikšni meti skupna izobraževalna točka sledi smernicam zapisanim v Huang s sodelavci (2020) ?

2. Kakšna je struktura video razlag na portalu Razlagamo.si?

$\mathrm{Z}$ družboslovno metodologijo analize, sinteze in komparacije smo primerjali portal Razlagamo.si s smernicami, ki so podane na osnovi kitajske izkušnje. V raziskavi smo nato uporabili kvantitativno neeksperimentalno metodo pedagoškega raziskovanja, s katero smo odgovorili na vprašanja o strukturi video razlag na portalu razlagamo.si

\section{Rezultati in diskusija}

\section{Usklajenost s smernicami izobraževanja v COVID-19 situaciji}

V Tabeli 1 prikažemo usklajenost skupne izobraževalne točke Razlagamo.si in jedrnih elementov, ki so priporočani za izobraževanje v COVID-19 situaciji (Huang in sodelavci, 2020). Uporabimo sledeče kazalnike: ++ - popolna usklajenost, +- delna usklajenost in - - ni usklajenosti

\section{Tabela 1}

Primerjava Razlagamo.si in jedrnih elementov kitajskih priporočil

\begin{tabular}{|l|c|l|}
\hline Jedrni element & Usklajenost & pojasnilo \\
\hline Zagotavljanja učinkovite internetne & ++ & MS Teams v Razlagamo.si \\
mreže, ki omogoča vsem učencem & & pogovorih omogoča sinhrono \\
(a) sinhrono poučevanje z video & & poučevanje; Arnesove spletne \\
konferencami, (b) uporaba (gledanje, & & učilnice v razlagamo.si razlagah \\
nalaganje) interaktivnih učnih virov & & omogočajo uporabo interaktivnih \\
(video posnetkov, iger ipd.) in (c) & & gradiv; Razlagamo.si facebook, \\
\hline
\end{tabular}




\begin{tabular}{|c|c|c|}
\hline $\begin{array}{l}\text { sodelovanje s sošolci preko socialnih } \\
\text { omrežij }\end{array}$ & & $\begin{array}{l}\text { twitter in instagram računi } \\
\text { omogočajo sodelovanje v socialnih } \\
\text { omrežij. }\end{array}$ \\
\hline $\begin{array}{l}\text { Izbira uporabniško prijaznih orodij } \\
\text { pri čemer je treba biti posebej } \\
\text { pozoren na to, da se učencev in } \\
\text { staršev ne obremeni z zahtevo po } \\
\text { uporabi mnogih aplikacij in platform. } \\
\text { Šole pozivajo, da učitelji } \\
\text { koordinirano uporabljajo iste } \\
\text { platforme. }\end{array}$ & ++ & $\begin{array}{l}\text { Uporabljena je enotna skupna } \\
\text { izobraževalna točka z enotnimi } \\
\text { orodji. }\end{array}$ \\
\hline $\begin{array}{l}\text { Zagotavljanje primernih } \\
\text { interaktivnih digitalnih virov, kot so } \\
\text { npr. video mikro tečaji, e-knjige, } \\
\text { simulacije, animacije, kvizi in igre. }\end{array}$ & ++ & $\begin{array}{l}\text { Razlagamo.si vsebuje interaktivne i- } \\
\text { učbenike http://www.iucbeniki.si/ }\end{array}$ \\
\hline $\begin{array}{l}\text { Vodenje učencev pri uporabi } \\
\text { učinkovitih učnih metod, kar } \\
\text { vključuje online skupnosti, ki } \\
\text { omogočajo reden človeški online stik } \\
\text { za preprečevanje občutka } \\
\text { osamljenosti in nemoči. }\end{array}$ & ++ & $\begin{array}{l}\text { Online skupnost je zagotovljena v } \\
\text { skupini Pogovorov: Svetovanje ob } \\
\text { težavah pri učenju. V skupino so } \\
\text { vključeni koordinatorji in študenti } \\
\text { psihologije in pedagogike Filozofske } \\
\text { fakultete Univerze v Mariboru, ki } \\
\text { podpirajo učenje in so učencem na } \\
\text { voljo za optimizacijo njihovih učnih } \\
\text { metod. }\end{array}$ \\
\hline $\begin{array}{l}\text { Promocija učinkovitih metod, ki } \\
\text { omogočajo raznolike poučevalne } \\
\text { strategije kot je npr. diskuje, učenje z } \\
\text { raziskovanjem, izkušenjsko učenje } \\
\text { ipd. }\end{array}$ & -- & $\begin{array}{l}\text { Na portalu trenutno ni tovrstne } \\
\text { promocije. }\end{array}$ \\
\hline $\begin{array}{l}\text { Zagotavljanje hitrih podpornih } \\
\text { servisov za učitelje in učence. }\end{array}$ & ++ & $\begin{array}{l}\text { Povprečni odzivni čas v podpornih } \\
\text { Pogovorih je med običajnimi urami } \\
\text { (med } 8.00 \text { in } 21.00 \text { ) manj kot } 1 \text { uro, }\end{array}$ \\
\hline
\end{tabular}




\begin{tabular}{|l|l|l|}
\hline & & $\begin{array}{l}\text { povprečni odzivni čas na e pošto } \\
\text { razlagamo@um.si je manj kot 1 dan. }\end{array}$ \\
\hline $\begin{array}{l}\text { Spodbujanje sodelovanja med vsemi } \\
\text { deležniki (npr. ministrstva, } \\
\text { raziskovalne organizacije, šole, } \\
\text { starši). }\end{array}$ & +- & $\begin{array}{l}\text { Skupno izobraževalno točko sicer } \\
\text { podpirajo vse institucije (MIZŠ, } \\
\text { ZZRS, šole, starši...), vendar je } \\
\text { aktivnega sodelovanja malo. }\end{array}$ \\
\hline
\end{tabular}

Iz tabele 1 je razvidno, da skupna izobraževalna točka dobro sledi usmeritvam izobraževanja med COVID-19 krizo, šibka točka je promocija učinkovitih metod poučevanja in učenja ter sodelovanje z vsemi deležniki. Verjamemo, da bo s časom tudi na teh področjih prišlo do izboljšanja, saj je pričakovati, da bo Razlagamo.si iz prostovoljnega gibanja prešla v nekoliko bolj strukturirano obliko delovanja.

\section{Struktura video razlag}

Na skupni izobraževalni točki se je 11. maja 2020 nahajalo 583 video razlag. Slika 1 prikazuje porazdelitev števila video razlag po vertikali. Ker imajo nekateri predmeti le umestitev v triletje osnovne šole, smo se odločili, da v tabeli 2 prikažemo število video razlag po triletjih in posebej za gimnazijo. V tabeli ni prikazanih 12 video razlag, ki se nanašajo na splošne strategije učenja in jih ni mogoče uvrstiti v določeno triletje oz. srednjo šolo, saj so uporabne povsod.

\section{Tabela 2}

Število video razlag po vertikali

\begin{tabular}{lcccc}
\hline & $\begin{array}{c}\text { prvo triletje } \\
\text { osnovne šole }\end{array}$ & $\begin{array}{c}\text { drugo triletje } \\
\text { osnovne šole }\end{array}$ & $\begin{array}{c}\text { tretje triletje } \\
\text { osnovne šole }\end{array}$ & $\begin{array}{c}\text { Srednja } \\
\text { šola }\end{array}$ \\
$\begin{array}{l}\text { število video } \\
\text { razlag }\end{array}$ & 86 & 125 & 260 & 90 \\
\hline
\end{tabular}

Pričakovano je največ video razlag najti v zadnjem triletju. Učenci so že dovolj samostojni, da se pri učenju na daljavo znajdejo, a kljub temu potrebujejo več vodenja kot srednješolci. Naše ugotovitve so v skladu z ugotovitvami drugih raziskav. Lo in Hew, po pregledu več raziskav o obrnjenem učenju (2017) ugotavljajo, da se obrnjene učilnice najpogosteje uveljavljajo pri učencih, ki so stari med 13 in 18 let. 
V tabeli 3 najdemo porazdelitev video razlag po predmetnih področjih, pri čemer smo upoštevali le predmete iz predmetnika $v$ javni osnovni in srednji šoli. Zato video razlage za glasbeno šolo (2 video razlagi), splošne napotke za učenje (12 video razlag) in mednarodno maturo pri matematiki (34 video razlag) niso zajete. Dodatno smo vključili še neobvezni izbirni predmet Računalništvo. Predmetov, kjer na Razlagamo.si ni video razlag (npr. slovenščina, nemščina, zgodovina..) v tabelo 1 nismo vključili. Pri matematiki in fiziki, ki imata video razlage tako v osnovni kot v srednji šoli, smo število ur, predvidenih v učnem načrtu, sešteli. Matematika ima npr. v osnovni šoli predvidenih 1378 ur, v srednji pa še dodatnih 560 .

Uteženo vrednost video razlag smo izračunali kot povprečje med številom video razlag in številom ur v učnem načrtu. Dobljeno vrednost smo zaradi lažje predstavitve pomnožili s sto in dobili t.i. normirano vrednost. Dodajamo, da normirana vrednost ne pomeni kolikšen del predmeta je pokrit z video razlagami, saj se pri določenih predmetih (npr. matematiki) video razlage prekrivajo. Za npr. trapez je video razlage lahko pripravilo tudi več učiteljev.

\section{Tabela 3}

Porazdelitev video razlag po predmetih

\begin{tabular}{llll}
\hline predmet & $\begin{array}{l}\text { Število } \\
\text { video razlag }\end{array}$ & $\begin{array}{l}\text { Stevilo ur } \\
\text { predmeta }\end{array}$ & $\begin{array}{l}\text { Normirana } \\
\text { vrednost }\end{array}$ \\
\hline Matematika & 389 & 1878 & 21 \\
Fizika & 31 & 344 & 9 \\
Naravoslovje & 13 & 175 & 7 \\
Angleščina & 6 & 656 & 1 \\
Tehnika in tehnologija & 6 & 140 & 4 \\
Biologija & 7 & 116 & 6 \\
Kemija & 2 & 134 & 1 \\
Spoznavanje okolja & 25 & 315 & 8 \\
Družba & 5 & 175 & 3 \\
Glasbena umetnost & 22 & 417 & 5 \\
Likovna umetnost & 10 & 487 & 2 \\
Šport & 2 & 834 & 0
\end{tabular}




\begin{tabular}{llll}
\hline Geografija & 4 & 221,5 & 2 \\
Naravoslovje in tehnologija & 9 & 210 & 4 \\
Računalništvo & 4 & 105 & 4
\end{tabular}

Ugotovimo, da ima najvišjo normirano vrednost matematika, sledi jih fizika, spoznavanje okolja in naravoslovje, najnižje normirane vrednosti imajo šport, kemija in angleščina.

Da bi odgovorili na zadnje raziskovalno vprašanje, smo predmete združili po področjih. Uporabili smo klasifikacijo ARRS (Javna agencija za raziskovalno dejavnost Republike Slovenije, 2017) na naravoslovje (matematika fizika, kemija, biologija, računalništvo), tehnika (naravoslovje in tehnika, tehnika in tehnologija), družboslovje, (geografija, družba, spoznavanje okolja), humanistika (angleščina). Umetnost in šport (likovna umetnost, glasbena umetnost) smo umestili v ostalo. Spoznavanje okolja je predmet, ki pokriva tako družboslovne kot naravoslovne vsebine, zato smo ga vključili enakomerno v obe področji, v vsako področje s polovico razlag. Pri naravoslovju in tehniki, smo v področje naravoslovje upoštevali tri četrtine razlag, $v$ tehniko pa četrtino razlag. Razporeditev po področjih ločeno za osnovno in srednjo šolo prikazuje Tabela 4

\section{Tabela 4}

Razporeditev video razlag po področjih

\begin{tabular}{|c|c|c|c|c|c|c|}
\hline \multirow{5}{*}{$\begin{array}{l}\text { osnovna } \\
\text { šola }\end{array}$} & $\begin{array}{l}\text { število video } \\
\text { razlag }\end{array}$ & 402,25 & 8,25 & 21,5 & 6 & 34 \\
\hline & število ur & 2297 & 192,5 & 554 & 656 & 1738 \\
\hline & normirana vrednost & 18 & 4 & 4 & 1 & 2 \\
\hline & $\begin{array}{l}\text { število video } \\
\text { razlag }\end{array}$ & 63 & & & & \\
\hline & število ur & 770 & & & & \\
\hline srednja šola & normirana vrednost & 8 & & & & \\
\hline skupaj & $\begin{array}{l}\text { število video } \\
\text { razlag }\end{array}$ & 465,25 & 8,25 & 21,5 & 6 & 34 \\
\hline
\end{tabular}




\begin{tabular}{lccccc}
\hline število ur & 3067 & 192,5 & 554 & 656 & 1738 \\
normirana vrednost & 15 & 4 & 4 & 1 & 2 \\
\hline
\end{tabular}

Ugotavljamo, da je normirana vrednost naravoslovja daleč najvišja. Ugotovitev dopolni meta-raziskavo, ki jo je izvedel Wagner s sodelavci (Wagner, Gegenfurtner, \& Urhahne, 2020). Ugotovili so, da so STEM področja bolj primerna za obrnjeno poučevanje srednješolcev kot ostala področja. V naši raziskavi ugotavljamo podobno, le da za osnovnošolsko populacijo.

\section{Predlogi za izvedbo pouka v času izrednih razmer in socialnega distanciranja}

Izraelski in angleški raziskovalci so oblikovali predlog ponovnega zagona sistemov (ekonomskih, izobraževalnih in drugih), ki omogoča varno izvedbo tudi v primeru novih valov izbruha virusa (Almanthari, Maulina, \& Bruce, 2020). Predlog stoji na šibki točki virusa in sicer na tridnevnem latentnem obdobju, po trenutnih dognanjih namreč mine v povprečju tri dni med okužbo in trenutkom, ko oseba postane kužna za druge. Zato predlagajo štiri dnevno delo/šolo, ki mu sledi deset dnevno delo/šola od doma.

Zaradi organizacijske optimizacije je naš predlog za ponovni zagon šolskega sistema jesen 2020 nekoliko prilagojen. Predlagamo, da se uvede "izmenski pouk" s tedenskimi izmenami:

- dve skupini učencev / dijakov se tedensko izmenjujeta v izmenah,

- $\quad \mathrm{v}$ tednu, ko je ena skupina doma in dela na daljavo, je druga $\mathrm{v}$ šoli in izvaja klasično obliko pouka.

Ta način predstavlja vsakokratno 9-dnevno karanteno po 5 dneh dela v šoli in s tem jasno sliko morebitnih okužb. Enak model bodo uporabile avstrijske šole že v tem šolskem letu (Almanthari, Maulina, \& Bruce, 2020). Predlagan način je tudi idealen način za uporabo metode obrnjene učilnice.

\section{Zaključek}

Kot lahko razberemo iz literature, lahko ovire pri e-poučevanju vključujejo številna vprašanja. Tehnologija in dostopnost do interneta, pomanjkanje učnega načrta za e-učenje in ocenjevanje in orodja za učinkovito ocenjevanje učencev omejujejo kaj učitelji lahko poučujejo. Motivacija pri učenju na spletu, zaupanje v uporabo tehnologije e-učenja in učiteljev odnos do spletnega pouka vpliva na to, kako in koliko se bo učenec naučil. Vse te 
ovire je treba upoštevati, ko smo soočeni z dogodkom, kot je pandemija, ki sili učitelje in učence, da se takoj prilagodijo na drugačen način poučevanja in učenja.

V prispevku ugotovimo, da je slovenska skupna izobraževalna točka Razlagamo.si v veliki meri usklajena s priporočili kitajskih raziskovalcev o tem, kako zagotavljati kakovostno učenje tudi med izbruhom COVID-19 (Huang s sodelavci, marec 2020). Ugotavljamo tudi, da se principi poučevanja obrnjene učilnice ohranjajo tudi med krizo, saj STEM področja močno prevladujejo, še posebej prevladuje matematika.

Zaradi izjemnega uspeha podporne točke in tudi z raziskavami dokazane vrednosti poučevanja z obrnjenim učenjem po celotni izobraževalni vertikali smo se odločili, da točka ostaja aktivna tudi po zaključku krize. Model Razlagamo.si je namreč učinkovit tudi v situaciji, ko je le del populacije učencev in dijakov vključen v izobraževanje na daljavo. Skupna izobraževalna točka bo v pomoč učiteljem, ki po načelih obrnjenega učenja pripravljajo gradivo tudi v nekrizni situaciji (npr. bolni učenci, učenci športniki, učenci z drugimi statusi).

\section{Literatura}

Almanthari, Z., Maulina, S., \& Bruce, S. (2020). Almanthari, A., Maulina, S., \& Bruce, S. (2020). Secondary School Mathematics Teachers' Views on E-learning Implementation Barriers during the COVID-19 Pandemic: The Case of Indonesia. Eurasia Journal of Mathematics, Science and Technology Education, 16(7). doi:https://doi.org/10.29333/ejmste/8240

Alon, U., Milo, R., \& Yashiv, E. (11.. 5. 2020). 10-4: How to Reopen the Economy by Exploiting the Coronavirus's Weak Spot. Pridobljeno 13.. 5. 2020 iz New York Times: https://www.nytimes.com/2020/05/11/opinion/coronavirus-reopen.html

Baseer Safi, A. (2019). ICT and integration in education: A meta-analysis. Journal of Emerging Technologies and Innovative Research, 6(6), str. 117-122.

Clark, D. B., Tanner-Smith, E. E., \& Killingsworth, S. S. (2016). Digital games, design, and learning: A systematic review and meta-analysis. Review of educational research, 86(1), str. 79-122.

Clark, R. C., \& Mayer, R. E. (2008). E--Learning and the Science of Instruction: Proven Guidelines for Consumers and Designers of Multimedia Learning, 2nd edition. San Francisco, CA: Pfeiffer/John Wiley \& Sons.

Delić, H., \& Bećirović, S. (2016). Socratic method as an approach to teaching . European Researcher Series A, 111(10), str. 511-517.

Gordon, N. A. (2014). Flexible Pedagogies: technology-enhanced learning. The Higher Education Academy. doi:https://doi.org/10.13140/2.1.2052.5760 
Hatlevik, O. E., Throndsen, I., Loi, M., \& Grudmundsdottir, G. B. (2018). Students' ICT self-efficacy and computer and information literacy: Determinants and relationships. Computers \& Education, 118 , str. 107-119.

Huang, R. H., Liu, D. J., Tlili, A., Yang, J. F., \& Wang, F. F. (2020). Handbook on Facilitating Flexible Learning During Educational Disruption: The Chinese Experience in Maintaining Undisrupted Learning in COVID-19 Outbreak. Beijing: Smart Learning Institute of Beijing Normal University.

Javna agencija za raziskovalno dejavnost Republike Slovenije. (16. februar 2017). Klasifikacije, šifranti. Pridobljeno iz https://www.arrs.si/sl/gradivo/sifranti/sif-vpp.asp.

Lipomi, D. J. (2020). Video for Active and Remote Learning. Trends in Chemistry. doi:https://doi.org/10.1016/j.trechm.2020.03.003

Lipovec, A., Zmazek, J., Lah, V., Zmazek, E., \& Zmazek, B. (2017). Z generation students' learning mathematics with e-resources. International journal of education and information technologies, 11, str. 105-110.

Liu, Y. (2019). Liu, Y. Using reflections and questioning to engage and challenge online graduate learners in education. Research and Practice in Technology Enhanced Learning, 14(3). doi:https://doi.org/10.1186/s41039-019-0098-z

Lo, C. K., \& Hew, K. F. (2017). A critical review of flipped classroom challenges in K-12 education: possible solutions and recommendations for future research. Research and Practice in Technology Enhanced Learning, 12(4). doi:https://doi.org/10.1186/s41039-016-0044-2

Means, B., Toyama, Y., Murphy, R., Bakia, M., \& Jones, K. (2009). Evaluation of evidence-based practices in online learning: a meta-analysis and review of online learning studies. Washington, DC: U.S.: Department of Education, Office of Planning, Evaluation and Policy Development.

Najafi, H., \& Heidari, M. (2019). Blended Learning and Academic Achievement: A Meta-Analysis. Iranian Distance Education Journal, 1(3), str. 39-48.

Overholser, J. C. (2018). Guided Guided Discovery: a Clinical Strategy Derived from the Socratic Method. International Journal of Cognitive Therapy, str. 124-139. doi:https://doi.org/10.1007/s41811-018-0017-x

Pérez-Sanagustín, M., Nussbaum, M., Hilliger, I., Alario-Hoyos, C., Heller, R. S., Twining, P., \& Tsai, C. C. (2017). Research on ICT in K-12 schools-A review of experimental and survey-based studies in computers \& education 2011 to 2015. Computers \& Education, 104, str. A1-A15.

Pinker, S. (2015). The sense of style: The thinking person's guide to writing in the 21st century. Penguin Books.

Scherer, R., \& Siddiq, F. (2019). The relation between students' socioeconomic status and ICT literacy: Findings from a meta-analysis. Computers \& Education, 138, str. 13-32.

Scherer, R., \& Teo, T. (2019). Unpacking teachers' intentions to integrate technology: A metaanalysis. Educational Research Review, 27, str. 90-109. doi:https://doi.org/10.1016/j.edurev.2019.03.001 
Scherer, R., \& Teo, T. (2019). Unpacking teachers' intentions to integrate technology: A metaanalysis. Educational Research Review, 27, str. 90-109.

doi:https://doi.org/10.1016/j.edurev.2019.03.001

Siddiq, F., \& Scherer, R. (2019). Is there a gender gap? A meta-analysis of the gender differences in students' ICT literacy. Educational Research Review, 27, str. 205-217.

van Alten, D. C., Phielix, C., Janssen, J., \& Kester L. (2019). Effects of flipping the classroom on learning outcomes and satisfaction: A meta-analysis. Educational Research Review, 28, str. 118. doi:https://doi.org/10.1016/j.edurev.2019.05.003

Viner, R. M., Russel, S. J., Croker, H., Packer, J., Ward, J., Sansfield, C., . . Booy, R. (2020). School closure and management practices during coronavirus outbreaks including COVID-19: a rapid systematic review. The Lancet. Childs \& Adolescent Health, 4(5), str. 397-404. doi:https://doi.org/10.1016/S2352-4642(20)30095-X

Wagner, M., Gegenfurtner, A., \& Urhahne, D. (2020). Effectiveness of the Flipped Classroom on Student Achievement in Secondary Education: A Meta-Analysis. Zeitschrift für Pädagogische Psychologie. doi:https://doi.org/10.1024/1010-0652/a000274.

Zhu, G., Suárez, M. I., Thompson, C. G., \& Peng, Z. (2019). A meta-analysis on the effect of flipped instruction on K-12 students' academic achievement. Paper presentation at the American Educational Research Association Annual Meeting. Toronto, Kanada. 